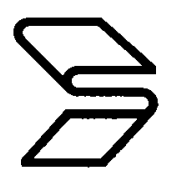





\title{
Politik für Bibliotheken
}

\author{
Die Bundesvereinigung \\ Deutscher Bibliotheksverbände (BDB) \\ im Gespräch
}

Birgit Dankert zum Ende ihrer Amtszeit als Sprecherin der BDB im Auftrag des Vorstandes

herausgegeben

von

Georg Ruppelt 
Die Deutsche Bibliothek - CIP-Einheitsaufnahme

Politik für Bibliotheken : die Bundesvereinigung

Deutscher Bibliotheksverbände im Gespräch :

Birgit Dankert zum Ende ihrer Amtszeit als Sprecherin der BDB / im Auftr. des Vorstandes hrsg. von Georg Ruppelt. - München : Saur 2000

ISBN 3-598-11436-2 (Broschierte Ausgabe) ISBN 3-598-11437-0 (Leinenausgabe)

Gedruckt auf säurefreiem Papier / Printed on acid-free paper

(C) 2000 K. G. Saur Verlag GmbH \& Co KG, München Part of Reed Elsevier

Alle Rechte vorbehalten / All rigths strictly reserved Jede Art der Vervielfältigung ohne Erlaubnis des Verlags ist unzulässig

Satz: Dr. Rainer Ostermann, München Druck: Strauss Offsetdruck, Mörlenbach Binden: Buchbinderei Schaumann, Darmstadt 